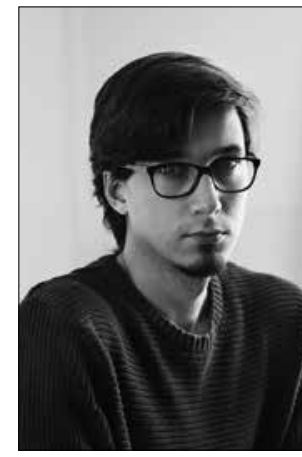

https://doi.org/10.24101/logos.2020.42

JUSTINAS KALINAUSKAS

Vytauto Didžiojo universitetas, Lietuva

Vytautas Magnus University. Lithuania

\title{
TIKROVĖS (RE)PRODUKCIJA XXI A. LIETUVOS TEATRE
}

\author{
(Re)production of Reality in the 21 st Century \\ Lithuanian Theatre
}

\begin{abstract}
SUMMARY
Based on the theoretical framework of the Theatre of the Real formulated by Carol Martin, this article (1) reviews the manifestations of the phenomenon of reality within the theater, (2) summarizes sociological and ontological perspectives, as well as the ones of Art Theory, and (3) articulates the mechanical changes that occur within the audience during the performance itself. Taking into account the contemporary practices extensively applied to the Lithuanian theater over the last two decades, the article (4) also deals with the most significant Lithuanian cases in which reality is being depicted/created on the theatrical stage.
\end{abstract}

\section{SANTRAUKA}

Šiame straipsnyje, remiantis Carol Martin suformuluota teorine Tikrovės teatro sandara, apžvelgiama tikrovẻs fenomeno raiška teatro lauke apibendrinant menotyrinę, sociologinę bei ontologinę perspektyvas ir artikuliuojant teatrinio akto metu atsiskleidžiančius funkcinius-mechaninius pokyčius, kurie vyksta auditorijoje. Ivertinant per pastaruosius du dešimtmečius Lietuvos teatre ekstensyviai taikomus šiuolaikinio teatro principus, straipsnyje Tikroves teatro požiūriu taip pat nagrinėjami reikšmingiausi Lietuvos teatro atvejai, darantys ryškią įtaką tikrovès vaizdavimo / kūrimo būdams.

\section{TIKROVĖS TEATRO OBJEKTAS}

Nuo XX a. septintojo dešimtmečio teatro bendruomenè (Vakaru Europoje ir JAV) pradejo aktyviai eksperimentuo- politines intencijas. Tokiame vyravusių 
paradigmų kaitos lauke, protestuodami prieš JAV vidaus (rasinè segregacija, LGBT bendruomenès kriminalizavimas, skirtingu soc. grupių diskriminacija) ir išorès (Vietnamo karas, intervencijos Kambodžoje ir Laose) politika, taip pat sekdami Vakarų kontrkultūros tendencijomis, alternatyvaus teatro lauke isitvirtino tokie kolektyvai kaip The Living Theatre, The Performance Group (nuo 1980 m. - The Wooster Group), The Open Theatre bei kiti, kurie teatro medijoje integravo naujas (re)prezentacijos praktikas, keite socialinius atlikejjų-publikos santykius bei rèmési autobiografine asmenine patirtimi, kaip politinès kritikos įrankiu (Martin 2013: 23). Siekdami reprezentuoti už teatro ribų veikiančią socialinę tikro$v e$ - ją galima gretinti su politine tikrove septintojo dešimtmečio JAV politinio klimato kontekste - teatrinių judejimu nariai aktyviai remdavosi asmeniniais (autoreferentiniais) naratyvais ${ }^{1}$, naudojo dokumentus, audio įrašus ir kitą audiovizualinę medžiagą siekdami ì sceną perkelti tikrovès dimensiją ir aktualizuoti teatro mediją kultūrinių septintojo dešimtmečio sąūdžių kontekste. Šiuo laikotarpiu vykusių procesu ir socialiniu lūžių lauke, pasak Tikrovés teatra tyrinèjančios Carol Martin, siekta atskleisti asmeninę ir viešąą tiesą tokiu būdu, kuri reikalautų naujos socialinès sąmonès (Martin 2013: 23).

Anot C. Martin, septintajame-aštuntajame dešimtmečiais vyravęs tikrovès suvokimas pasižymèjo maskavimo samprata, paprastai susijusia su politinès dimensijos ir individo priešprieša. Tiesa (teisybè) tuo laikotarpiu suvokta kaip paslèpta nuo visuomenès po melo uždanga, kurią griauti bandè septintojo dešimtmečio kontrkultūros judejjimai siekdami atskleisti "tikrąją tikrovę" (Martin 2013: 23). Jos teigimu, tokio socialinio pasipriešinimo principą galima ižvelgti radikalaus feminizmo atstovès Carol Hanisch (1942) išpopuliarintame termine asmeninis yra politinis ${ }^{2}$ (Martin 2013: 24), kuris - šią savoka, remiantis C. Hanisch, galima interpretuoti kaip asmeninès emancipacijos per viešą socialini atsiskleidimą metodą - yra plačiai aptinkamas Tikrovés teatro praktikose. Panašias idejjas C. Martin pastebi ir Bertoldo Brechto epinio teatro teorijoje bei Erwino Piscatoriaus teatre, kur žiūrovai skatinti veikti ir užimti aktyvią bei kolektyvinę tikrovę manifestuojančią poziciją (Martin 2013: 15, 17).

C. Martin Tikrovés teatra (kaip tyrimo objektą) identifikuoja ne vien per išorines kategorijas, bet, pirmiausia, santykyje su socialinés tikrovés kontekstu ir istorija. Remiantis C. Martin, Tikrovés teatras išsiskiria principu (re)formuotis savo struktūrinès sandaros viduje, o ne vien per referavimą $i$ išorinius reiškinius principa, kuris yra iprastas reprezentacijomis paremtame konvenciniame teatre, iprastai vaizduojančiame redukuotą ir apvalytą tikrovės versiją. $\mathrm{O}$ Tikrovés teatra C. Martin kildina iš XX a. antroje pusejje pradejjusios isivyrauti realistinès epistemologijos, igalinusios teatrą kreipti savo žvilgsni i tikrovès (pirmaisiais atvejais - $i$ tikroviškumo) dimensiją. Tokia fundamentų slinktis skatino naujojo teatro kūrejjus remtis autentiškomis ir/ arba faktinèmis patirtimis, tačiau atsisa- 
kant realistinės vaidybos kanonu, kuriuos iprasta sieti su reprezentavimo ir teatralizavimo metodologine mokykla (Martin 2013: 22). Tikrove šiuo laikotarpiu vyravusiuose kūrybiniuose diskursuose labiau tapatinta su autentiškumu ir tiesa bei, tam tikrais atvejais, asmenine emancipacija, individo autonomija ir kolektyviškumu (Martin 2013: 23).

Tikroves teatro praktikose pasireiškè dvi pagrindinès kūrybinès srovès: pirmajai būdingas gana radikalus teatrinių elementu perkonstravimas; antroji srovè atpažistama dramaturgijos idejos permąstyme, kuris pasireiškè aktyviu citavimu, pirminiu šaltinių (pavyzdžiui, interviu) ir kitų empirinę tikrovę ženklinančių dokumentų naudojimu (Martin 2013: 22). Remiantis C. Martin, galima identifikuoti pastarosios sroves turinio kaitos modelius: dokumentinị teatra, pažodžiui cituojama teatra (ang. k. verbatim theatre), realybe paremta teatra, faktu teatra, liudijimo teatra (ang. k. theatre of witness), teismo teatra, ne-fikcijos teatra, teatro bendruomenes pasirodymu atkūrima, karo ir mūšio rekonstrukcijas bei autobiografini teatra (Martin 2013: 5). O pirmoji srovè pasižymi ne vien turinio, bet ir erdviniu, socialiniu bei performatyviu santykiu kaita teatrinio akto momentu. Jenn Stephenson nurodo, jog pastarasis būdas siekia konstruoti faktinę esatị ir nagrinè- ja tikrovę kaip fenomena, o ne tik siekia teatrinèmis priemonėmis atskleisti scenoje tikrumą (Stephenson 2017).

Žvelgiant apibendrintai, Tikroves teatro legitimacija galima sieti su poststruktūralistiniam permąstymui palankia sociokultūrine terpe, paveikta postmodernybès naratyvuose fundamentaliai pakitusios pasaulio sampratos, kurioje suardoma modernybëje įsitvirtinusi binarinè pasaulio paradigma, aiškinanti istoriją kaip progresa, o moralę - kaip aiškius orientyrus turinčią sistemą (Jameson 2002). Šiame kontekste tikrovès, kaip objektyvios koordinačiu sistemos, suvokimas tampa nebeimanomas ir pasiklysta tarp teksto, diskurso bei simuliacijos. Anot C. Martin, „postruktūralistai norèjo atskirti prasmès gyli nuo meno, kuris suprantamas kaip nesibaigiantis simuliakras" (Martin 2013: 67). Poststruktūralistineje paradigmoje tikrovès fenomenas tuo pačiu nutolo nuo savo socialiai ižemintos, institucionalizuotos ir kanonizuotos moderniosios prigimties, tapo fragmentuotas, daugialypis ir išskaidytas i i skirtingas individualizuotas multitikroves, kuriose pasireiškè tikrovès simuliacijos (hipertikrove, žr. Jean Baudrillard), performatyvios tikrovès (pavyzdžiui, performatyviai atliekamos lytinès tapatybès, žr. Judith Butler) ir kitos savarankiškos prieigos.

\section{SOCIALINIS TIKROVĖS ASPEKTAS}

Socialines tikroves sampratą galima formuluoti remiantis Peterio L. Bergerio ir Thomaso Luckmanno knyga The Social Construction of Reality (1966), kurioje konstruojamas sisteminis modelis, api- brèžiantis, kaip visuomenè(-ès) konstituoja socialinę tikrovę trimis dialektiškai susijusiais jos produkavimo etapais (Berger, Luckmann 1991): a) eksternalizacija, nurodančia visuomenę kaip žmogaus 
sukurtą socialinę struktūrą; b) objektyvacija, apibrěžiančia visuomenę kaip objektyvią realybę; c) internalizacija, nagrinèjančiai žmogaus kaip socialinio produkto sampratą.

Pirmuoju etapu epistemologinė žinojimo paradigma pasireiškia kaip tam tikras tikrumas, konstituojantis tikrovès reiškinių realumą ir apibrèžiantis jų sandarą. Tokiame procese visuomenè veikia kaip tam tikras mediatorius, kaupiantis ir dalijantis žinojimą smulkesniems visuomenès dariniams. Didele dalimi toks žinojimas ir jo distribucija pasireiškia kasdieniame (individo) gyvenime (Berger, Luckmann 1991: 31). O objektyvizacija pasireiškia kaip kolektyvinè-istorinè realybè, sąlygojanti visuomenès narių individualias tikrovès sampratas veikti universaliais modeliais (pagal visuomeninès realybės normas). Toks individualus savęs produkavimas pasireiškia kaip socialine ịmone arba kaip institucionalizacija, kurią P. Bergeris ir T. Luckmannas ivardijo Homo socius terminu (Berger, Luckmann 1991: 69). Institucijų legitimacija, anot Bergerio ir Luckmanno, yra manifestuojama per galios ir autoriteto prizmę - institucinè tikrovè negali egzistuoti be legitimacijos, o legitimacija leidžia realizuoti galią. Toki prisitaikyma, dar kitaip suvokiamą kaip asmeninès / individualios prasmès priskyrimą objektyviam socialiniam ivvykiui, galima vadinti individo tikrovès internalizacija, kurią P. Bergeris ir T. Luckmannas teigia esant sudarytą iš socializacijos, antrinès socializacijos bei subjektyvios tikrovès transformacijos (Berger, Luckmann 1991: 149).
Papildant tikrovès konstrukcijos teorija taip pat pravartu remtis Corneliuso Castoriadis (1922-1997) socialinio ịsivaizdavimo sąvoka, aprašyta knygoje The Imaginary Institutions of Society (1998), apibrěžiančia, kaip individualios vaizduotès paradigma keičiama kolektyviniu isivaizdavimu platesniame socialiniame kontekste. Pasak Castoriadis, didžioji dalis žmonijos istorijos praslinko tokiomis sąlygomis, kai žmonès nekvestionuodami prièmé viska, kas jų institucinèje tradicijoje jiems buvo pristatyta, o toliau remdamiesi šia (šiomis) tradicija(omis) kūrè būsimas taisykles ir būdus, atitinkančius pirminę institucinę logiką ${ }^{3}$. Šių instituciju ašimi Castoriadis laiko ịsivaizduojamas reikšmes, kurios organizuoja visas visuomenines vertes ir veiklas, kylančias iš visuomenę sudarančių individų. Castoriadis teorijoje tokie veiksmai (individualūs ir kolektyviniai poelgiai), būdingi visuomenès funkcionavimui, yra neįmanomi be ịsivaizdavimo, kuris niekados neveikia autonomiškai, bet visados eina kartu su kažkuo: intelektu, patyrimu, tikrove (Castoriadis 1997: 197). Šiuo požiūriu, ir pačios visuomeninės funkcijos visados yra kažko konkretaus funkcijos: igalinimo arba išnaudojimo (Castoriadis 1997: 21), o ju funkcija pasireiškia tik apibrèžiant jos reikšmę. Socialinis ịsivaizdavimas čia veikia tik kontekste socialinių reikšmių, kurios sąlygoja bet kokią socialinę funkciją. Castoriadis taip pat pažymi, kad jokia visuomenė negali funkcionuoti be i̊sivaizduojamų reikšmių, o įsivaizdavimas priklauso pačiam visuomenès institutui, siekiančiam viskam, kas ji pristato, suteikti prasmę. 


\section{TIKROVĖS REPREZENTACIJOS KAITA}

Žvelgiant platoniškuoju požiūriu, teatrine tikrove - tai terpè, pasireiškianti / veikianti už fizinio lauko ribų: ją galima atpažinti nurodose ir reprezentacijose, nurodančiose i idealiuosius (turinio) konceptus (Platonas, Valstybe, 7 knyga). Konvencinèse teatrinio vaizdavimo praktikose galima pastebèti aiškius platoniškuosius fundamentus, pernešančius prasmę iš savalaikio patyrimo i̇ menamą poetinę sferą - toks principas atitinka platoniškają ontologiją kurioje visa tai, kas pasireiškia, yra tapsmo procese. Tikrovés teatro objektui tuo tarpu artimesnè yra Aristotelio metafizika, kurioje objektai yra suvokiami savo pačių būtimi - jie, nereferuodami $i$ idealiąsias transcendentines formas, žymi savo pačių materialu objektiškuma, kaip savarankišką savitiksli reiškini (Politis 2004). Tokia konceptuali prielaida tiek ontologine, tiek epistemologine samprata atitinka Tikrovés teatro pažadą atskleisti tiesos objektą savo tikruoju pavidalu.

Tikroves teatro ontologinę genezę taip pat galima nagrinèti vokiečiu idealizmo tradicijoje, remiantis Immanuelio Kanto (1724-1804) Grynojo proto kritikoje $e^{4}$ (1781) išdėstyta transcendentalinio idealizmo teorija. Čia aktualiausia yra laikiškumo kontekste I. Kanto pateikta sekos analogija, kai patyrimo kaita pasireiškia dvejopai: a) kaip išorinio judančio (animuoto) objekto apraiška, kuri sąlygoja suvokejjo patyrimą (Kant 1998: 167) - toks patyrimo kaitos būdas iprastai pasireiškia reprezentaciniame teatre kaip auditorijos reginys, bet nekeičia konvenciniu santykių tarp auditorijos ir atlikejjo/scenos; b) kaip patyrimas, kylantis iš suvokèjo saviorganizaci- jos - kuomet suvokèjas savarankiškai tyrinejja aplinka, taip keisdamas savo santyki su objektu ir išgyvendamas naują patyrimo dinamiką (Kant 1998: 167, 184).

Janelle Reinelt nurodo, jog teatrinès reprezentacijos konvencijos paveikia ir socialines konvencijas bei teatro tikrovès apraiškas. Toks procesas, anot jos, prasidejjo anksčiau negu septintajame dešimtmetyje isitvirtino performatyvumo paradigma - reprezentacijos ribas kvestionavusius eksperimentus galima identifikuoti jau siurrealistų bei dadaistu praktikose, taip pat Antonino Artaud, Vasilijaus Kandinskio, Vsevolodo Mejercholdo ir kitụ kūrejjų darbuose (Reinelt 2002: 158). Remdamasi Jacques'u Derrida, J. Reinelt nurodo, jog teatras niekados negali pabėgti nuo reprezentacijos, kaip ir repeticija negali išvengti pasikartojamumo (Reinelt 2002: 165). Nickas Kaye tuo tarpu pastebi, kad performanso mene ir šiuolaikinio teatro pastatymuose pasireiškiantis "tikro laiko“ (angl. k. real time) veiksmas veikia kaip reakcija i konvencinio teatro paradigmoje vyraujantį požiūrị i (iprastą) teatrinę struktūra, sudarytą iš auditorijos ir reprezentacijos elementu. "Tikrame laike“ reprezentacija netenka turètos reikšmès, ji gali būti pakeičiama objektais, dokumentais, multimedija ir erdvès transformacijomis. Performatyvus teatras, pasak Kaye, kèle iššūkị fiksuotam, pakartojamam, kiekybiškai apčiuopiamam, objektiškam teatro suvokimui. "Gyvi veiksmai“, kurie užfiksuojami ir išsaugojami per dokumentavimą ir artefaktus bei objektus ir daiktus, išvengè lengvos atomazgos ir pateko i liudijamą choreografiją (Kaye 2018: 275). 
O Michaelis Kirby pažymi, kad nors vaidyba paprastai reiškia simuliacija, reprezentaciją arba îkūnijima, nebūtinai kiekvienas atlikimas yra laikytinas vaidyba. Tokia atlikimo samprata bene labiausiai atsiskleidè hepeninguose, kurių atlikèjai dažniausiai nebūdavo kuo nors daugiau, negu jie patys, arba nesistengdavo reprezentuoti kažko, esančio už ju empirinès realybès laiko ir erdvès - simuliuoti arba apsimesti (Kirby 2003: 309). Tarp vaidybos (konvenciniu atveju) ir nevaidybos (hepeninguose) M. Kirby nurodo esant distancija, kurioje telpa skirtingos atlikimo praktikos. Apskritai Tikrovés teatro praktikose aktorius dažniau yra įvardijamas atlikejju, o ne aktoriumi - tai daug svarbesnè pozicija, negu tik teksto ir režisieriaus nurodymų interpretantas (Martin 2013: 30). Anot C. Martin, aktoriai (net ir Tikrovés teatre) ne visiškai vaidina ir ne visiškai būna savimi - jie perduoda kitų žmonių liudijimus, kuriuos gali pritaikyti ir sau patiems. Todèl tiesa, kuri pateikiama per aktoriaus / atlikèjo asmeninę patirtį teatre yra daug paveikesnè, negu bet kokia objektyvi tiesa (Martin 2013: 38). Atlikèjo emancipacija tuo pačiu pasireiškè kitų kūrèjų, dramaturgo autoriteto mažèjimu arba visišku dramaturgo figūros atsisakymu bei režisieriaus darbo perskirstymu kitiems kūrèjams.

\section{Tikrovès mediacija}

Pasak Phillipo Auslanderio (2008), gyvas atlikimas interpretuotinas ne kaip fizinio artumo ir buvimo kartu sąlyga, bet kaip laiko koreliacija. Auslanderis teigia, kad būtinybè identifikuoti gyvybingumo (ang. k. liveness) reiškinius kyla iš atsako radijui ir komunikacinems technologijoms bei krizès būsenoje kuriant aiškią atsvarą gyvai transliacijai ir/arba įrašytai informacijai: ,"atsakas ị šią krizę buvo terminologinè skirtis, kuri siekè išsaugoti aiškias ankstesnes dichotomijas tarp dviejų atlikimo lygių - gyvo ir įrašyto" (Auslander 2008: 59). İrašinejjimo technologija, pasak jo, gyvumui suteikè būti, kuri pasireiškè aiškia skirtimi tarp atliekamo ir naujojo varianto. Transliavimo technologijos, kita vertus, sugriovè iki tol buvusi vienas kitą papildanti santyki tarp gyvo ir įrašyto atlikimo: „Žodis „gyvas“ [ang. k. live] buvo įdiegtas naudoti kaip dalis žodyno, sukurto išlaikyti šiai krizei, apibūdinant ją ir grąžinant buvusią skirti diskursyviai, net jeigu ji daugiau nebegali būti išlaikyta patyrimiškai“" (Auslander 2008: 60). Tad buvusi papildanti dialektinè sąveika tarp gyvo ir irašyto buvo atkurta kaip binarinė opozicija. Auslanderis pažymi, kad ši tendencija, kuri prasidejjo analoginès technologijos eroje, yra išlaikoma iki pat šios dienos ir toliau formuoja mūsų ìsivaizdavimą apie "gyvumą" (Auslander 2008: 60).

Chiel Kattenbelt esejje The Role of Technology in the Art of the Performer (Kattenbelt 2006) teigia, kad irašymo technologijų, tokių kaip audio ir video, apraiška sutrikdo iprastą laiko ir erdès suvokimą bei atitinka Immanuelio Kanto laiko ir erdvès sampratą Grynojo proto kritikoje, jog skirtingi laikai yra sekventiški, bet ne simultaniški, tačiau skirtingos erdvès visados esti simultaniškos: „Teatrinès vaizduotès principų ekspansija naudojant gyvą video [transliaciją. - J. K.] bei i̇rašytą garsą gali būti glaustai charakterizuota kaip erdvès sulaikinimas ir laiko 
suerdvinimas“ (žr. Bay-Cheng 2010: 87). Panašią funkciją ižvelgia ir Birgit Wiens, nurodydama intermedialaus atlikimo transgresiją už konkrečios vietos ir / arba laiko ribų. Pasak B. Wiens, intermediali erdvè, vadovaujantis tokiu princi$\mathrm{pu}$, nebūtinai turi būti iš anksto iggyvendinta / sukurta - ji gali būti suvokiama kaip laikina, dinamiška ir kopleksiška erdvinè konfigūracija, sukuriama vien atlikimo proceso metu (Wiens 2010: 94). Sarah Bay-Cheng, reaguodama į šiuolaikines laikinumo koncepcijas, pažymi, jog skaitmenizacija - cituojant ją: „medijos transformacija į duomenis" - didele dalimi buvo didesnio „kultūrinio perkodavimo" dalimi (Bay-Cheng 2010: 86). O Alice Rayner slinktį nuo fizinio atlikimo i kibererdvę gretina su slinktimi iš erdvès ontologijos i atliekama laika (ang. $\mathrm{k}$. performance of time).

C. Martin teigia, jog tikrovès mediacija geba kontroliuoti visuomenès elgesi, i antrą planą nustumdama "gyvo" gyvenimo elgesio normas, pakeisdama jas prodiuseriu ir televizijos režisieriu įsivaizdavimu apie įdomiausią (tuo pačiu ir pelningiausią) tikrovès versiją. O Tikroves teatras geba identifikuoti tokius žalingus tikrovès mediacijos būdus ir naudoja medijas kitokiais principais: kaip tikrovès indikatorių; kaip įrankị atskleisti žmonėms simuliacijos prasiskverbimo i gyvenimą požymius; arba kaip priemonę atskleisti populiariosios kultūros dezinformaciją, pavyzdžiui, naujienu šaltiniuose (Martin 2013: 14). Medijuota teatrine tikrové gali pateikti keletą speficiniu išraiškos galimybių, viena jų - simultaniškumas, kurio pavyzdžių (nors simultaniškumas yra vienas esminiu postmodernaus teatro bruo- žų) galima aptikti ir išimtinai medijų kultūroje, pavyzdžiui, ankstyvojoje televizijoje, kur simultaniškumas pasireiškè kaip esminis televizijos principas - iš dalies todèl radijas ir televizija turèjo tam tikrą laiko dimensija, aptinkamą ir teatre (Pečiulis 2005: 155).

Lietuvos teatro atveju, tikrovès mediaciją dažniau yra ịprasta patirti kaip simultanišką ir sinchronišką gyvo vaizdo transliavimą (vaizdo mediaciją) toje pačioje atlikimo erdveje, kurioje veikia ir gyvas aktorius. Vienu pirmųju (plačiai apžvelgtų) bandymų Lietuvos teatre panaudoti vaizdo transliaciją buvo režisieriaus Gintaro Varno režisuotame spektaklyje Nusikaltimas ir bausme (2004), kuriame vaizdo mediacija veikè kaip vienas iš personažų, užtikrinančių naratyvo progresiją. Vèliau tiesioginè vaizdo transliacija ekstensyviai naudota Dainiaus Gavenonio ir Jūratès Paulèkaitès parengtame spektaklyje-performanse Uždaras vakaras (2008). Vis tik produktyviausiai vaizdo transliavimą $2012 \mathrm{~m}$. panaudojo trupe No Theatre, išbandžiusi ši principą spektaklyje Mr. Fluxus arba Šarlatanai? (2012), kuriame, galima teigti, sèkmingai įtvirtintos „lietuviškos" vaizdo mediacijos konvencijos, vèliau plačiai naudotos ivvairiuose antrojo dešimtmečio šiuolaikiniuose šalies teatro projektuose. Čia tiesioginè vaizdo transliacija reikšmingai prisidejjo ne tik prie spektaklio istorijos pasakojimo, bet veikè ir kaip mechanizmas, vaizdo pagalba sujungiantis auditoriją ir scena, tokiu būdu deteatralizuojant sceninį vyksmą, arba, priešingai, auditoriją priartinant prie teatrinés tikrovés, o teatrą - prie socialinés tikrovés lauko. Vèliau tiesioginę transliaciją trupé naudojo spektakliuose 
Nematomi monstrai (2013), Kaligula (2014), tačiau panašaus kokybinio efekto neišgavo. Vaizdo mediacija nuo 2015 m. tampa ekstensyvi daugelyje Artūro Areimos spektaklių: Nerykèlis (2015), Medejjos kambarys (2016), Antikristas (2017), Virimo temperatūra 5425 (2017), Aklieji (2018) ir vèlesniuose darbuose. Čia vaizdo mediacija ne(be)atveria naujos tikrovès dimensijos ir veikiau naudojama kaip konvencinis režisūrinis mechanizmas, postmoderniu principu keičiantis ir modifikuojantis reprezentuojamą scenini vyksmą bei fiktyvu teatriness tikroves naratyvą.

\section{TIKROVĖS (RE)PRODUKCIJA}

Socialinès tikrovés apraiškos konvenciniame teatre dažniausiai pasireiškia atsitiktinai ir yra suvokiamos kaip trūkis fiktyvios teatrinès dinamikos audinyje: aktoriui padarius klaida, pamiršus tekstą gendant scenos infrastruktūrai arba ivykstant kitiems techniniams nesklandumams. C. Martin nuomone, socialinés tikrovés įsiveržimas į teatrinį aktą paprastai nèra laukiamas reiškinys, jam įvykus, neretai pradedama kvestionuoti teatro samprata ir prasmè (Martin 2013). Žiūrèjimo akte veikianti auditorijos struktūra nors ir nèra unifikuota, bet vadovaujasi tam tikra stebejjimo-dalyvavimo etika. Galima pastebèti, jog identifikuojamos socialinés tikrovés intervencija ị teatrinę tikrovę griauna - tokia fragmentacija laikina ir gali būti gretinama su Erikos Fischer-Lichte apibrèžta liminalu$m o^{5}$ (Fischer-Lichte 2013) būsena - ir pačią žiūrovų bendruomenę, nes kolektyvinis žiūros aktas tampa dekonsoliduojantis ir verčia žiūrovus individualiais suvokejjais. C. Martin tokị teatro ir tikrovės persidengima, kai nyksta ribos tarp scenos ir tikro pasaulio, laiko esminiu Tikroves teatro objektu (Martin 2013: 4). Tikroves teatro dèmuo, pasak jos, gali igauti labai tiesiogines tikrovès formas, akimirksniu pakeisti erdvès atmosfera bei stabilaus socialinio audinio integra- luma, kuomet socialinés tikrovés artefaktai teatro erdvejje yra suardomi. Priešingas variantas - kai socialine tikrove "perima“ teatrinio akto kontrolę, tokiu būdu „deteatralizuodama" vaidinimą. Tiesioginis, bekompromisis tikrovès įsiveržimas teatre, pasak C. Martin, pažeidžia iprastą konvencija, jog „teatras neturi būti tikras" (Martin 2013: 21). Tokia empirinès realybès ir teatrinès (sąlygiškos) tikrovès kolizija apibūdinama kaip „ontologinè teatro abejonè" (Martin 2013: 21).

\section{Tikrovès įsiveržimas}

Tikrovès įsiveržimas Lietuvos teatro lauke pasireiškia bent keliais būdais. Pavyzdžiui, reprezentaciniame teatre ryškiausiai pastaraji dešimtmeti socialinés tikroves motyvas atveriamas Jono Vaitkaus spektaklyje Visuomenès priešas (2011), kuriame tikrovès įsiveržimas atskleidžiamas simbolinėmis scenografijos priemonèmis ir tikros-menamos teatro sienos "griūtimi“. Tokia meninè figūra, kita vertus, nekuria jokių reikšmingu socialiniu transformaciju ir išlieka poetinio naratyvo lauke. Ryškiau tikrovès insiveržimas pastebimas Krystian Lupa spektaklyje Didvyriu aikšte (2015), spektaklio metu uždegamos šviesos žiūrovu salèje ir pakeičiamos scenos-auditorijos 
erdvinès pozicijos, pertraukiant teatrinès tikrovés nuoseklumą ir îvedant socialinès tikrovés dèmeni, keičianti auditorijos introspekciją socialiniu pastabumu ir (galima) savirefleksija. Vaiva Lanskoronskytè taikliai pastebi, jog sprendimas spektaklyje apšviesti žiūrovų salę tuo pačiu sugriauna saugumo ir stabilumo jausmą žiūrovams (Lanskoronskytè 2015). Toks sprendimas taip pat laikinai sukuria reliatyvius galios santykius: vienu atveju žiūrovai gali palyginti sceninę reprezentaciją su temos kontekstu; kita vertus, panaudota režisūrinè priemonè objektyvuoja pačius žiūrovus ir keičia ju socialinius statusus.

Ivairaus lygio ir intensyvumo tikrovès issiveržimus taip pat galima stebèti performatyviame meta-šokio spektaklyje Contemporary (2013), kuriame socialinès tikrovès gylis pasireiškia per ironišką Lietuvos šokio mokyklos dekonstrukciją savo tematika primenančia No Theatre spektakli Telefonu knyga (2010), kuriame buvo reflektuojamas šalies teatro laukas autobiografines aktoriu prakalbas, socialini komentarą bei diskusiją su auditorijos dalyviais apie tikrovę ir asmenines patirtis, kurios tiesiogiai nèra atskleidžiamos spektaklio sceninèje reprezentacijoje. Tuo tarpu Artūro Areimos teatre pastaruosius keletą metu integruojamos auditorijos dalyvavimo formos tikrovès dimensijas atveria gana specifiniu būdu - čia interaktyvūs momentai pasireiškia per auditorijai sukeliamą trauminę patirti, o dalyvavimas nebūtinai produktyviai keičia prasminị turinị, tačiau įneša papildomas socialines įtampas, kurios žiūrovą transportuoja iš socialinés tikrovés i realią akistatą su instituciniu teatro kuriamu nesaugu- mo jausmu, kuris yra neiprastas konvenciniame dramos teatre.

Sėkmingai socialinès tikrovés įsiveržimą suvaldo režisierè Kamilè Gudmonaitè su dramaturge Tekle Kavtaradze dalyvaujamajame audio spektaklyje Sapnavau sapnavau (2019). Čia socialinę tikrovę sąlygoja ne tik medijuotu būdu užmezgamas santykis su nuteistaisiais, bet ir papildomai atskleidžiamas institucinès tikrovès karkasas (šią aliuziją galima užčiuopti erdvès redukcijoje i visišką tamsą), sisteminiu būdu atskiriantis vienas visuomenès grupes nuo kitos. Naudojamos režisūrinès strategijos šiuo atveju ne tik sukuria saugios akistatos su kaliniais pojūti, bet ir medijuotomis audio priemonėmis simuliuoja gyvą santykį tarp dviejų individų žiūrovo ir nuteistojo - kuris, kitu atveju, būtų neįmanomas socialinejje ir institucinèje visuomenès realybèje.

\section{Tikrovès simuliacija}

Vienas iš pasireiškiančių simuliacijos požymių yra simuliuotos tikrovès vertimas tikroviška, arba dar tikresne už tikrovę, kuri nèra simuliuota. Tokia naujoji tikrovė geba pasireikšti pakeisdama (išstumdama) pirminę tikrovę ir užimdama jos vieta, taip pakeisdama atvaizdą simuliuotu. Jean'ui Baudrillard'ui (19292007) simuliuojamų objektų ženkliškumas nebeapsiriboja reprezentacija, tuo pačiu ir nèra redukuotas vien ì simboli simuliakras privalo būti hipertikroviškas, kad sugebètų išstumti originalą iš patyrimo proceso (Baudrillard 1993). Baudrillard'o hipertikrovę galima interpretuoti kaip tikrovę, nusavinančią ir pakeičiančią ne tik buvusi tikrovès pavidala, bet kartu ir tos pirminès tikrovès, 
arba tikrovès originalo, struktūrą. Tokia nauja tikrovè stokoja realybès originalo substancijos, todèl izvardijama kaip hipertikrové (Baudrillard 2002).

Dalis Lietuvos teatro reiškinių, kuriuos galima būtuc priskirti Tikrovés teatro laukui, balansuoja tarp sceninès tikrovès, kaip autonomiško reprezentacijos turinio, ir siekio produkuoti organišką realybès versiją (tam tikrais atvejais - imituoti socialine tikrovę ir jos daugiasluoksniškumą), nukreiptą i auditoriją (priešingai negu reprezentacijos atveju, kuomet tikrovė yra izoliuota scenoje). Tokiuose pavyzdžiuose sceninės kokybės nèra naikinamos vardan socialinés tikrovés, bet, veikiau, socialine tikrové spektaklyje tampa pakeičiama naujaja savo pačios versija, t. y. tikrovès mechanizmais, kurie yra „beveik" tokie patys, kaip jie pasireiškia socialinëje (institucinëje) tikrovèje, ir teatrinis sąlygotumas perauga i natūralistinę dimensija, tačiau per detales arba izsiterpimą $\mathfrak{i}$ tikrovès elementus kūrèjai siekia užšifruoti pagrindinę tikrovès simuliacijos semantinę medžiagą - tokiu būdu teatrą ir jo keliamus klausimus užmaskuodami pateikiamoje (simuliuotoje) empirinèje kasdienybejje.

Šis metodas ryškiausiai atskleidžiamas dviejuose pastarųjų dviejų metu para-teatriniuose reiškiniuose: fotografės Neringos Rekašiūtès eksperimentinèje performatyvioje parodoje Atomine tapatybe (2018), surengtoje sovietinès tikrovès likučius talpinančiame (autentiškame) bute Visagine, kurio erdves apgyveno aktoriai Marijus Povilas Elijus Martynenko ir Gerda Čiuraitè - jie čia atliko ịprastus buitinius veiksmus: gaminosi valgyti, gulejo lovoje, maudèsi vonioje, nekur- dami sąmoningų socialinių barjerų tarp vienos erdvès dalyvių; ir režisierès Monikos Klimaitès aplinkos spektaklyje-audioture Vieno buto istorija (2018), vykusiame Justiniškių mikrorajone Vilniuje esančiame sovietini laikotarpi menančio interjero bute. Klimaitès spektaklio veikèjas, skirtingai negu parodoje Atomine tapatybé, egzistuoja menamoje erdvejje jo vienpusis santykis su spektaklio lankytojais kuriamas audio izrenginiu pagalba. Tuo tarpu žiūrovai gauna nurodymus, kaip pažinti juos supančią aplinką kaip suprasti ausinėse girdimo pasakotojo istoriją ir kaip šioje simuliacijoje identifikuoti santyki su pačiais savimi.

Abiejų spektaklių atveju, organizuota patyrimo erdvė ir jos sukonstruotas autentiškumo efektas veikia kaip pagrindinis elementas, transportuojantis žiūrovus i kitą tikrovès versiją. Vieno buto istorija ir Atomine tapatybe autentišką interjerą naudoja per jame esančius atpažistamus ženklus ir simbolius, nešančius norimą pastebimai nostalgišką - reikšmę. Tokiu būdu yra imituojamas erdvinis realizmas, leidžiantis transportuoti žiūrovusdalyvius ì produkuojamą tikrovę. Socialinés tikrovés (re)produkcija kuria taip pat ir naują socialini santyki tarp bendros erdvès dalyviu, $\mathfrak{i}$ kuriuos yra orientuotas šių spektaklių išorinis procesas: Atominès tapatybès žiūrovai-lankytojai gali dalyvauti tarpusavio interakcijose, veikti aplinkos medžiagiškumą ir savarankiškai keisti savo erdvinius santykius su performatyviais buto elementais. Vieno buto istorija režisierès Klimaitès vienas iš siekių - taip pat inicijuoti ir žiūrovų bendruomenę, kurios nariai „išgyventų būrio jausmą" (Spektaklio anonsas 2018). Šio 
spektaklio turinys, kita vertus, yra introspektyvus ir orientuotas $\mathfrak{i}$ individualu žiūrovo-dalyvio patyrima, o galimybių socialinèms interakcijoms spektaklyje mažai: čia buto lankytojai dèvi ausines ir sovietinį interjerą tyrinejja archeologiniu žvilgsniu. Nepaisant to, spektaklio modelis daro didelę itaką santykio su aplinka stiprèjimui. Abiem atvejais konstruojama erdviné patirtis turi kitą semantini krūvị nei tas, kuris būtu pasiekiamas institucinèje teatro aplinkoje.

\section{IŠVADOS}

Remiantis Carol Martin, Tikroves teatro prielaidu galima ieškoti postmoderniosios paradigmos isitvirtinime $\mathrm{XX}$ a. antrosios pusės globaliame kultūros lauke, taip pat septintojo dešimtmečio Vakarų alternatyvaus teatro angažuotume, teatro kūrejjams siekiant sutelkti pakankamas galios priemones, leidžiančias dalyvauti politiniame diskurse. Šiuo laikotarpiu vykę sociokultūriniai Vakaru visuomeniu pokyčiai skatino asmeninès emancipacijos procesus, kurios siekta ir per naujos autentiškos tikrovès kūrimą teatro scenoje.

Ankstyvosios Tikrovés teatro praktikos pasireiškė dvejopai: kaip sceninis dokumentinių šaltiniu (pa)statymo mechanizmas (pavyzdžiui, dokumentinis, autobiografinis arba liudijimo teatras) arba kaip naujos tikrovès konstravimas ir struktūrinių teatro elementų reorganizavimas. Tokiam Tikrovés teatro pobūdžiui reikšminga yra socialinés tikroves samprata, kuri teatro lauke geba pasireikšti skirtingu produktyvumu: kaip teatrinès tikrovés ir reprezentacijos trūkis arba kaip i auditorijos dinamiką orientuotas fenomenas, reikšmingai keičiantis teatro žiūrovu santykius ir sukuriantis naujas publikos galios pozicijas. Instituciniuose santykiuose toks socialinés tikrovés pobūdis pasireiškia kaip savęs produkavimas ir individualios socialinès įmonés kūrimas, kuri P. Bergeris ir T. Luckmannas yra ivardije Homo socius, o C. Castoriadis socialinio isivaizdavimo sąvoka. Abiem atvejais socialiniai institutai sąlygoja ir socialinés tikrovés manifestacija, jos pobūdị bei kokybę.

Tikroves teatro objektas lokalizuojamas itampoje tarp reprezentacijos (teatrinès tikrovés) ir socialinès tikrovés, kurią analogiškai galima būtu palyginti su itampa tarp atlikejjo ir žiūrovo. Ši konfliktą galima sieti tiek su socialine teatro konstrukcija, tiek su ontologine teatro tikrovess sandara - abiem atvejais slinktis nuo tikrovès reprezentacijos prie tikrovès (re)produkcijos pasireiškia nauja estetine ir/arba mechanine teatro logika. Reikšmingą itaką šiam pokyčiui daro naujosios technologijos, multimedija, vaizdo ir garso mediacija bei kitos priemonès - ši tendencija išryškëja ir Lietuvos teatre, kuriame vaizdo mediacija per pastaraji dešimtmeti galutinai isitvirtino šiuolaikinejje scenoje ne vien kaip estetinis elementas, bet ir kaip funkcinis irankis, keičiantis patyrimo būdus ir jų kokybę.

Keičiantis teatrinès reprezentacijos praktikoms, Lietuvos teatro lauke vis plačiau išbandomi nauji tikrovès produkavimo/reprodukavimo būdai, aktyviau 
teatriniame akte ivedantys socialinés tikrovés aspektus - atskirais atvejais teatrinis aktas apskritai praranda savo fundamentalius demenis - nebesitenkinama turinio reprezentacija ir siekiama auditorijai sukelti tiesiogini patyrimą. Tokia patirtis ryškiausiai atsiskleidžia dviem būdais: kaip tikrovès i̇siveržimas žiūros akte, kuris provokuoja asmeninę žiūrovo akistatą su socialiniu medžiagiškumu; arba kaip tikrovès simuliacija - jos metu teatrinė aplinka pakeičiama naujai (re)konstruojama socialinès tikrovés versija, kuri daro reikšmingą itaką teatrinio turinio formavimuis arba jo pokyčiams.

\section{Literatūra}

Auslander Phillip. 2008. Liveness, Performance in a mediatized culture, Second edition. London, New York: Routledge.

Bay-Cheng Sarah. 2010. Temporality, Sarah BayCheng et all (eds.). Mapping Intermediality in Performance: 95-90. Amsterdam: Amsterdam University Press.

Baudrillard Jean. 1993. Symbolic exchange and death. Translated by Iain Hamilton Grant. Sage Publications.

Baudrillard Jean. 2002. Simuliakrai ir simuliacija. Iš prancūzų k. vertè Marius Daškus. Vilnius: Baltos lankos.

Berger Peter L., Luckmann Thomas. 1991. The Social Construction of Reality: A Treatise in the Sociology of Knowledge. Harmondsworth: Penguin books.

Castoriadis Cornelius. 1997. The Castoriadis Reader. Translated and edited by D. A. Curtis. Hoboken: Blackwell publishers.

Castoriadis Cornelius. 1998. The Imaginary Institution of Society. Cambridge: The MIT Press.

Fischer-Lichte Erika. 2013. Performatyvumo estetika. Iš vokiečiuc k. vertẻ Jūratė Pieslytė. Vilnius: Menų spaustuvè.

Hanisch Carol. 1969. The Personal is Political. Prieiga per internetą: <https://webhome.cs.uvic. $\mathrm{ca} / \sim$ mserra/AttachedFiles/PersonalPolitical.pdf> [žiūrèta 201912 10]

Jameson Fredric. 2002. Kultūros posūkis: rinktiniai darbai apie postmodernizma (1983-1998). Iš ang-
Apibendrinant galima daryti išvada, jog metodologinis Tikrovés teatro modelis pirmiausia yra irankis veikti ne tik per socialinę bendruomenę, bet taip pat ir su pačia socialine bendruomene. Toks $\mathrm{Ti}$ krovés teatro pobūdis iš esmès keičia nusistovejjusias teatrines paradigmas, kai atskleidžiami nauji pastatymo strategiju būdai ir naujai îprasminama empiriškai patiriama tikrovè. Tikrovés teatras, atsisakydamas reprezentaciju ir struktūralistinès prasminès komunikacijos principu, tuo pačiu keičia pati teatrini buvimą ir nuo suvokimo struktūrų juda auditorijos patyriminès būsenos link.

lų k. vertė Auksė Mardosaitè. Vilnius: Lietuvos rašytojų sajungos leidykla.

Kant Immanuel. 1998. Critique of pure reason. Translated and edited by P. Guyer, A. W. Wood. Cambridge: Cambridge University Press.

Kattenbelt Chiel. 2006. De rol van technologie in de kunst van de performer, Henk Havens, Chiel Kattenbelt, Eric Ruijter and Kees Vuyk (eds.). Theater \& Technologie: 12-31. Amsterdam: Nederlands Theater Instituut.

Kaye Nick. 2018. On Objects, Performance Research, Vol. 12, Issue 4 (2018): 273-278.

Kirby Michael. 2003. On acting and non-acting, Philip Auslander (ed.). Performance, Critical Concepts in Literary and Cultural Studies, V. I: 309323. London and New York: Routlede.

Lanskoronskytė Vaiva. 2015. Bet pasaulis ir yra absurdiškos mintys, Bernardinai.lt. Prieiga per internetą: < http://www.menufaktura.lt/?m=1025\&s= $61070>$ [žiūrèta: 201912 05]

Martin Carol. 2013. Theatre of the Real. Basingstoke: Palgrave Macmillan.

Pečiulis Žygintas. 2005. Televiziju transformacijos procesas: technologinis ir komunikacinis aspektai, Knygotyra 45: 155-167.

Pelias Ronald J., Van Oosting James. 2003. A paradigm for performance studies, Philip Auslander (ed.). Performance, Critical Concepts in Literary and Cultural Studies Volume I: 215-231. London and New York: Routlede. 
Platonas. 1981. Valstybe். Iš senosios graikų k. vertė J. Dumčius. Vilnius: Mintis.

Politis Vasilis. 2004. The Routledge Philosophy Guidebook to Aristotle and the Metaphysics. Routledge.

Reinelt Janelle. 2002. The Politics of Discourse: Performativity meets theatricality, SubStance, Vol. 31, No. 2/3: 201-215.

Stephenson Jenn. 2017. Theatre of the Real in the Age of Post Reality. Prieiga per internetą: <https://

\section{Nuorodos}

1 Richardo Schechnerio (The Performance Group) nuomone, nors atlikèjai vaidindavo, bet taip pat atlikdavo daugybę kitų veiksmų ir neslèpdavo savo asmenybiu, o atsiskleisdavo kartu su kuriamu vaidmeniu, arba pateikdavo save kaip opoziciją kuriamiems personažams (žr. Bertoldą Brechtą). Užuot slèpęsi užkulisiuose, kai neatlikdavo vaidmenų, atlikejjai buvo skatinami atskleisti žiūrovams savo asmenybę kartu su paruoštais vaidmenimis (Pelias, Van Oosting 2003: 222).

2 Ang. k. the personal is political. Plačiau žr.: Hanisch Carol. 1969. The Personal is Political. Prieiga per internetą: <https://webhome.cs.uvic. ca/ mserra/AttachedFiles/PersonalPolitical.pdf > [žiūrèta: 201912 10] realtheatre.blog/2017/01/18/theatre-of-the-realin-the-age-of-post-reality/ $\geq$ [žiūrèta: 201212 12] Wiens Birgit. 2010. Spatiality, Sarah Bay-Cheng et all (ed.). Mapping Intermediality in Performance: 91-96. Amsterdam: Amsterdam University Press.

Spektaklio anonsas. 2018. „Vieno buto istorija“ Justiniškių daugiabutyje tyrinès žmogaus laimę, menufaktura.lt. Prieiga per internetą: <http:// www.menufaktura.1t/?m=1199\&s=68509 > [žiūrèta: 201912 20]

3 C. Castoriadis pažymi, jog kiekviena visuomenè kuria jai būdingas ir ją determinuojančias taisykles, o kartu ir savas institucijas, pavyzdžiui, kalbą, kultūrines ir socialines taisykles, priemones, religija, idealus, taip pat autoriteto vaidmeni visuomenèje bei jo legitimaciją (Castoriadis 1997).

4 Naudojama 1998 m. redakcija anglų kalba.

5 Liminalumo sąvoka nurodo individo būsena, kai naujas socialinis santykis dar nèra ittvirtintas, tačiau senasis jau yra praradęs savo pozicija, pavyzdžiui, žiūrovas iš ịprastų stebejjimo kategoriju perkeliamas i dalyvaujamąji teatro lauka, taigi ir kitokių socialinių santykių tikrovę, tačiau dar nèra spejęs jame aklimatizuotis. 